\title{
Lip Prominence Using Different Reference Plones
}

\author{
Dr Resina Pradhan,' Dr Anjana Rajbhandari,2 Dr Manju Bajracharya, ${ }^{3}$ \\ Dr Pushkar Manandhar, ${ }^{4}$ Dr Surendra Maharjan ${ }^{5}$ \\ 1.3.4.5 Assistant Professor, ${ }^{2}$ Professor, People's Dental College \& Hospital, Kathmandu, Nepal
}

Correspondence: Dr Resina Pradhan; Email: resina.shrestha@gmail.com

\section{ABSTRACT}

Introduction: Facial beauty lies on lip prominence which in turn is the reflection of dental and skeletal relation of the jaws beside the lip morphology. Thus, orthodontist has control over lip prominence to enhance beauty by altering skeletal and dental relation. Hence analyzing lip prominence is essential for the success of orthodontic treatment. The aim of the present study is to determine lip prominence using different reference planes and secondly to assess sexual differences in lip prominence.

Materials \& Method: lateral cephalograms of 43 (23 males and 20 females) Brahmins aged 18 - 27 years were collected. They were having dentally: Angle's Class I molar and canine relation with normal overjet and overbite and skeletally: normal jaw relationship, symmetric face with acceptable facial profile, without craniofacial abnormalities. Linear distance was measured in lateral cephalograms from most prominent point of the lip to reference planes of different analysis system. Comparative test was conducted within Brahmins to check gender diversity at significance level $p \leq 0.05$.

Result: Comparison of lip prominence of male and female Brahmins were found to have no statistically significant differences except for the upper lip to Burstone B line $(p \leq 0.05)$ and lower lip to Holdaway $H$ line $(p \leq 0.05)$. When means of males and females were compared males were found to have more protrusive lips.

The Result of this study indicates protrusive lips of Brahmins compared to the established norms of Caucasians as analyzed with reference plane of different analysis system namely Ricketts, Steiners and Burstones. Sushners analysis showed retrusive lips indicating retrusive lips of Brahmins as compared with Black population.

Conclusion: During orthodontic treatment planning lip prominence should be emphasized based on gender and ethnicity.

Keywords: lip prominence, soft tissue analysis.

\section{INTRODUCTION}

Analysis of orthodontic treatment focuses on lip prominence along with hard tissue analysis.' A paradigm shift from hard tissues to soft tissues has been realized in the recent years due to the fact that the dental and skeletal corrections are eventually reflected upon the overlying soft tissue drape. ${ }^{2}$ For the purpose many analysis has been put forward like Ricketts E line, Steiners S line, Burstones B line, Holdaways $\mathrm{H}$ line and Merrifields $\mathrm{Z}$ angle. ${ }^{3}$ Later as the analysis was performed in different ethnic groups, ethnic diversity has been proven as in Sushners Su line in Black population. ${ }^{4}$ Greater ethnic differences in soft tissue relationship than in skeletal and dental relationship has been reported. ${ }^{5}$ Knowing the Brahmins lip prominence with reference to different reference planes holds the clinical value for orthodontic treatment planning.

\section{MATERIALS AND METHOD}

Ethical approval was obtained from the Institutional Review Board (IRB - IOM). Radiographs taken were in natural head position with maximum intercuspation and lips in light contact. 6.7

\section{Cephalometric Method}

Using tools as 0.003 inches thick matte acetate tracing paper, 0.5 micro tipped pencils, intense light of view box, soft tissue landmarks was outlined manually. For better visualization of the soft tissues, cardboard is used to mask the radiopaque area. ${ }^{3}$ Their names were blinded to prevent researcher bias. Soft tissue landmarks was localised and the linear distance from the most prominent point in the outline of the lip to the reference lines of different analysis system namely Steiners, Ricketts, Burstone, Sushner, Holdaway and Merrifield $Z$ angle was measured using the measuring scale and protractor nearest to $0.5 \mathrm{~mm}$. Lip position ahead of the line was considered as positive and behind as negative. Landmarks were relocalised and average of differences was considered. Definition of landmarks and the reference planes are presented in table 1 and 2 . Different reference lines of the study are presented in figure 1.

\section{Statistical Analysis}

Intraobserver variation in measurements performed in a week interval was statistically analyzed using 


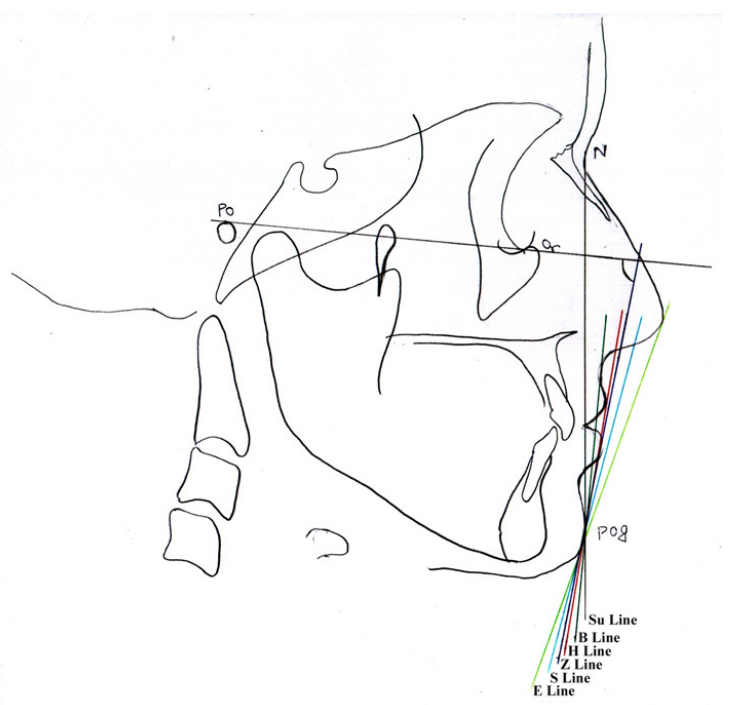

Figure 1: Reference Planes and Angle

Table 1. Cephalometric Landmarks ${ }^{8}$

\begin{tabular}{|c|l|l|}
\hline No. & \multicolumn{1}{|c|}{ Landmarks } & \multicolumn{1}{c|}{ Description } \\
\hline 1 & Nasion Ns & The point of deepest concavity of the soft tissue contour of the root of the nose \\
\hline 2. & Pronasal Ps & The most prominent point of the nose \\
\hline 3. & Subnasal Sn & The point where the lower border of the nose meets the outer contour of the upper lip \\
\hline 4. & Labrale superius Ls & The median point in the upper margin of the upper membranous lip \\
\hline 5. & Labrale inferius Li & The median point in the upper margin of the lower membranous lip \\
\hline 6. & Soft tissue Pogonion Pog & The most prominent point on the soft tissue contour of chin \\
\hline 7. & Porion Po & The superior most point of external auditory meatus \\
\hline 8. & Orbitale Or & Inferior most point of inferior orbital rim \\
\hline
\end{tabular}

Table 2. Reference Planes and Z Angle (2,3,

\begin{tabular}{|c|l|l|}
\hline No. & \multicolumn{1}{|c|}{ Name } & \multicolumn{1}{c|}{ Description } \\
\hline 1. & Steiners Line & Line from soft tissue pogonion to middle of S formed by lower border of nose \\
\hline 2. & Ricketts Line & Line from tip of the nose to pogonion \\
\hline 3. & Burstone Line & Line from subnasal to soft tissue pogonion \\
\hline 4. & Sushner Line & Line from soft tissue to nasion to soft tissue pogonion \\
\hline 5. & Holdaway Line & Line from upper lip to soft tissue pogonion \\
\hline 6. & Z Angle & Angle formed by soft tissue pogonion to most procumbent lip with FH plane \\
\hline
\end{tabular}

students "t" test. Descriptive statistics were drawn from the quantitative data for each variables using IBMSPSS (Statistical Package for Social Science) version 20. Comparison of male and female within the group is performed with Mann-Whitney $U$ Test at significance level 0.05. Coefficient of variation for different reference lines was performed to analyze which reference plane has lesser flexibility of data. ${ }^{6}$

\section{RESULT}

Intraobserver variation in measurements performed for 20 lateral cephalograms in a week interval was statistically not significant. The established norms of different analysis system, descriptive statistics of male and female Brahmins and their statistical comparison is presented in table 3.

Linear distance, Labrale superius to Burstone $B$ line of male Brahmins was significantly greater $(p \leq 0.05)$ than the Female Brahmins. Linear distance from Labrale Inferiorus to Holdaway $\mathrm{H}$ line was significantly greater ( $\mathrm{p} \leq 0.05$ ) in females than males. Lip prominence with other reference planes though greater is not statistically significant.

Among different reference lines Coefficient of variation is found to be least with Sushners reference plane (32.49 
Table 3. Descriptive Statistics of Male and Female Brahmins and their Statistical Comparison

\begin{tabular}{|c|c|c|c|c|c|c|c|c|c|c|c|c|c|}
\hline \multirow{2}{*}{ Measurements } & \multirow{2}{*}{\multicolumn{2}{|c|}{$\begin{array}{c}\text { Norms } \\
\text { Male (23) }\end{array}$}} & \multicolumn{4}{|c|}{ Male (23) } & \multicolumn{4}{|c|}{ Female (20) } & \multicolumn{3}{|c|}{ Test } \\
\hline & & & Mean & SD & Min & Max & Mean & SD & Min & Max & Diff & p Value & Sig \\
\hline \multicolumn{14}{|l|}{ Steiner } \\
\hline \multicolumn{14}{|l|}{ S Line } \\
\hline UL & 0 & $\mathrm{~mm}$ & 0.130 & 1.180 & -3 & 2 & -0.650 & 1.565 & -3 & 2 & -0.780 & 0.116 & NS \\
\hline LL & 0 & $\mathrm{~mm}$ & 0.870 & 1.546 & -2 & 4 & 0.700 & 2.250 & -3 & 5 & -0.170 & 0.457 & NS \\
\hline \multicolumn{14}{|l|}{ Ricketts } \\
\hline \multicolumn{14}{|l|}{ E Line } \\
\hline UL & -4 & $\mathrm{~mm}$ & -2.910 & 3.554 & -10 & 6 & -4.600 & 2.563 & -9 & 0 & -1.687 & 0.138 & NS \\
\hline LL & -2 & $\mathrm{~mm}$ & -1.150 & 2.703 & -7 & 4 & -1.850 & 2.739 & -6 & 3 & -0.698 & 0.405 & NS \\
\hline \multicolumn{14}{|l|}{ Burstone } \\
\hline \multicolumn{14}{|l|}{ B Line } \\
\hline UL & 3.500 & $\mathrm{~mm}$ & 4.040 & 1.397 & 1 & 6 & 3.100 & 1.210 & 1 & 5 & -0.943 & 0.021 & $S^{*}$ \\
\hline LL & 2.200 & $\mathrm{~mm}$ & 3.570 & 2.019 & 0 & 7 & 3.100 & 2.150 & -1 & 7 & -0.465 & 0.474 & NS \\
\hline \multicolumn{14}{|l|}{ Holdaway } \\
\hline \multicolumn{14}{|l|}{ H Line } \\
\hline LL & 0 & $\mathrm{~mm}$ & 0.090 & 1.125 & -1 & 3 & 0.950 & 1.395 & -1 & 4 & 0.863 & 0.030 & $S^{*}$ \\
\hline \multicolumn{14}{|l|}{ Sushner } \\
\hline \multicolumn{14}{|l|}{ Su Line } \\
\hline UL & 9.050 & $\mathrm{~mm}$ & 9.610 & 2.856 & 5 & 15 & 8.350 & 2.943 & 4 & 13 & -1.259 & 0.214 & NS \\
\hline $\mathrm{LL}$ & 7.250 & $\mathrm{~mm}$ & 6.910 & 2.448 & 3 & 10 & 6.250 & 2.863 & 1 & 11 & -0.663 & 0.415 & NS \\
\hline \multicolumn{14}{|l|}{ Merrifield } \\
\hline Z Angle & 80 & Deg & 73.700 & 7.112 & 60 & 84 & 76.600 & 7.556 & 63 & 90 & 2.904 & 0.311 & NS \\
\hline
\end{tabular}

UL - Upper Lip, LL - Lower Lip, S - Significant, NS - Not Significant, p-Probability *p $\leq 0.05 ; * * p \leq 0.01 ; * * * p \leq 0.001$

\% upper lip / $39.94 \%$ lower lip) indicating least amount of flexibility of data with this reference plane.

\section{DISCUSSION}

Lip prominence is the reflection of skeletal and dental relation beside the influence of the soft tissue drape of the lip. ${ }^{2}$ Lateral cephalograms collected for this study were of individuals having skeletally and dentally normal relation with acceptable facial profile. ${ }^{5}$ Hence the sample of this study were of individuals having normal anteroposterior and vertical dimension. Lateral cephalograms were taken in maximum intercuspation with lips in light contact which allows less muscular stress and is also most commonly presented lip posture in public. ${ }^{6}$

The age of our sample lies between 18-27 years so values obtained in this analysis are applicable for adults. Lips are most prominent during adolescent due to increase in its thickness and decreases with age. Due to thinning of the lips with age, fuller lips should be preferred during treatment planning. ${ }^{10,-12}$

Ricketts $E$ line (-2.91 male / -4.60 female upper lip) (-1.15 male / -1.85 female lower lip), Steiners $S$ line (0.13 male /
-0.65 female upper lip) (0.87 male / 0.70 female lower lip), Burstones B line (4.04 male / 3.10 female upper lip, $p \leq 0.05$ ) (3.57 male / 3.1 female lower lip) Sushners Su line (9.61 male / 8.35 female upper lip) (6.91 male / 6.25 female lower lip) indicated prominent upper and lower lips in males compared to females. In Holdaway $\mathrm{H}$ line where lower lip is compared in reference to upper lip females were found to have more protrusive lower lip than males 10.09 male / 0.95 female lower lip $p \leq 0.05$ ). In Merrifields Z angle where the reference line lies in the most prominent lip indicated prominent lip in males than females (73.7 male ( 76.6 female). Here the reference line passes through the prominent upper lip in case of males and prominent lower lip in case of females. This indicates that though the lower lip is more prominent in females compared to upper lip, it is less prominent than that of male lips.

Greater thickness of lips in males could be the contributing factor for the prominent lips in male Brahmins. ${ }^{13}$ Pogonion to nasion perpendicular which signifies the chin position indicates posteriorly positioned chin in male Brahmins than female Brahmins, could be the contributing factor for females to have prominent lower lips than males. ${ }^{14}$ The five 
reference planes of this analysis has one of their location in the chin. Preference of lip prominence in reference to chin position has been observed in earlier studies. ${ }^{15}$

Brahmins lip prominence was found to be greater compared to established norms given by Ricketts, Burstone and Holdaway, which could be due to dentoalveolar protrusion in Brahmins compared to Caucasians.$^{14}$ These findings are supported by Merrifields Z angle (80 Caucasians and 75 in an average for Brahmins). Lip prominence in Brahmins were found to be lesser compared to Blacks as shown by Sushners analysis (9.61 male / 8.35 female upper lip) (6.91 male / 6.25 female lower lip). Here again lip thickness, nasal inclination and chin prominence may play a role in lip prominence bringing ethnic diversity. ${ }^{4}$

One of the most important measurements while deciding extractions is the lip prominence in comparison with the standardized peer group. Hence the values obtained in this study has clinical application. ${ }^{16}$

Least coefficient of variation meaning lesser flexibility of data in Sushners Su line (upper lip 32.49\%, lower lip 39.94\%) could be because this line among others lies closest to the skeletal structures. Beside this line is not influenced by individual variation of nose inclination and chin prominence. ${ }^{6}$

Caucasians prefer fuller lips and African American prefer flatter lips than the norms of that race indicating attractive face may not necessarily follow norms of the race. The study samples are of individuals with acceptable facial profile. Preference of facial profile may or may not match the norms achieved in this group. Further study regarding preference of lip prominence can be performed so as to find out whether the attractive group falls under the established norms from this study. ${ }^{17}$

\section{CONCLUSION}

Brahmin males with prominent lips than Brahmin females presented sexual dimorphism. Upper and lower lip prominence was found to be different than the established norms in reference to different reference planes. Hence there is a need for standardized comparison with the peer group for orthodontic diagnosis and treatment planning.

\section{OJN}

\section{REFERENCES}

1. Charles J. Burstone. Lip posture and its significance in treatment planning Am J Orthod Dentofac Orthop. 1967, 53:4:262-284.

2. Holdaway RA. Soft tissue cephalometric analysis and its use in orthodontic treatment planning. Am J Orthod Dentofac Orthop.1983, $84: 1: 1-28$.

3. Jacobson A., editors. Radiographic cephalometry: From Basics to Videoimaging. London: Quintessence Publishing Co. Inc, 1995 , p. 77-95.

4. Hwang H, Kim W, McNamara JA. Ethnic differences in the soft tissue profile of Korean and European-American adults with normal occlusion and well balanced faces. Angle Orthod. 2002,72:1:72-80.

5. Miyajima K, McNmara JA, Kimura T, Murata S, Tizuka T. Craniofacial structure of Japanese and European-American Adults with normal occlusion and well balanced faces. Am J Orthod Dentofac Orthop. 1996, 110:4:431-8.

6. Hsu BS. Comparison of five analytic reference lines of the horizontal lip position: their consistency and sensitivity Am J Orthod Dentofac Orthop. 1993, 104:4:355-60.

7. Basciftci FA, Usyal T, Buyukerkmen A. Determination of Holdaway soft tissue norms in Anatolian Turkish Adults. Am J Orthod Dentofac Orthop. 2003, 123:4:395-300

8. Athanasios AE. Orthodontic Cephalometry. London: Mosby-Wolfe, 1995, p.49-51

9. Erbay EF, Canikliog CM, Erbay SK. Soft tissue profile in Anatolian Turkish adults: Part I. evaluation of horizontal lip position using different soft tissue analysis. Am J Orthod Dentofac Orthop. 2002, 121:1:57-64.

10. Buschang PH, Fretty K, Campbell PM. Can commonly used profile plane be used to evaluate changes in lower lip position. Angle Orthod. 2011, 81:4:557-563.

11. Torlakovic L, Ferovig E. Age_related changes of the soft tissue profile from the second to the fourth decaded of life. Angle Orthod.2011 81:1:50-57.

12. Nicole GP, Tiziano B, McNamara JA. The ageing craniofacial complex: A longitudinal cephalometric study from late adolescence to late adulthood. Am J Orthod Dentofac Orthop. 2008, 134:4:496-505.

13. Mahato RK, Kafle D, Singh PK, Sonika Khanal, Khanal S. Variation of facial soft tissue thickness in Nepalease adult orthodontic subjects. Orthod J Nep. 2018, 8:2:22-28.

14. Pradhan R, Rajbhandari A, Shrestha S.L. McNamara's cephalometric analysis of adult Brahmins of Kathmandu. Orthod J Nep. 2016, 6:2: $10-14$

15. Modarai F, Donaldson JC, Naini FB. The influence of lower lip position on the perceived attractiveness of chin prominence. Angle Orthod. 2013, 83:5:795-800.

16. Oliver BM. The Influence of lip thickness and strain on upper lip response to Incisor retraction. Am J Orthod Dentofac Orthop. 1982, 82:1:141-9.

17. Hideki L, Nakata S, Nakasima S, Counts AL. Anteroposterior lip positions of the most favored Japanese facial profiles. Am J Orthod Dentofac Orthop. 2005, 128:2:206-11. 